\title{
Chikungunya Virus Vaccines: Platforms, Progress, and Challenges
}

\author{
Victor R. DeFilippis
}

\section{Contents}

1 Introduction: Chikungunya Ecology and Economic Impact ….................................... 82

2 CHIKV Replication and Immune Reactivity ……....................................................... 83

3 Animal Models of CHIKV Infection and Immunity ……............................................... 85

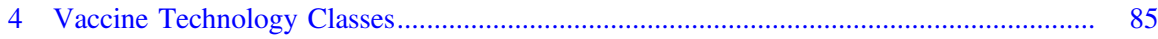

4.1 Live Attenuated Viral Vaccines ......................................................................... 86

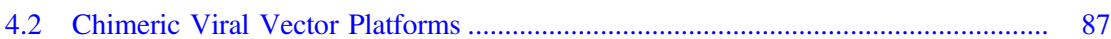

4.3 Inert Antigen Vaccines ............................................................................... 91

4.4 Nucleic Acid Based Vaccines ................................................................................. 93

5 Priorities for and Barriers to Clinical CHIKV Vaccine Development............................... 94

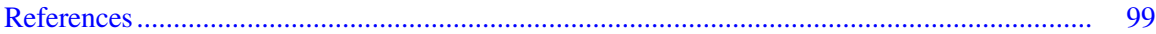

\begin{abstract}
Chikungunya is a clinically and economically important arbovirus that has spread globally in the twenty-first century. While uncommonly fatal, infection with the virus can lead to incapacitating arthralgia that can persist for months to years. The adverse impacts of viral spread are most severe in developing low- and middle-income countries in which medical infrastructure is insufficient and manual labor is an economic driver. Unfortunately, no prophylactic or therapeutic treatments are approved for human use to combat the virus. Historically, vaccination has proven to be the most efficient and successful strategy for protecting populations and eradicating infectious disease. A large and diverse range of promising vaccination approaches for use against Chikungunya has emerged in recent years and been shown to safely elicit protective immune responses in animal models and humans. Importantly, many of these are based on technologies that have been clinically approved for use against other pathogens. Furthermore, clinical trials are currently ongoing for a subset of these. The purpose of this review is to provide a description of the relevant immunobiology of Chikungunya infection, to present
\end{abstract}

\footnotetext{
V. R. DeFilippis $(\bowtie)$

Vaccine and Gene Therapy Institute, Oregon Health and Science University, 505 NW 185th Ave, Portland, Beaverton, OR 97006, USA

e-mail: defilipp@ohsu.edu

Current Topics in Microbiology and Immunology (2022) 435: 81-106

https://doi.org/10.1007/82_2019_175

(C) Springer Nature Switzerland AG 2019

Published online: 24 July 2019
} 
immune-stimulating technologies that have been successfully employed to protect against infection, and discuss priorities and challenges regarding the future development of a vaccine for clinical use.

\section{Introduction: Chikungunya Ecology and Economic Impact}

Chikungunya virus (CHIKV) is an arthritogenic arbovirus belonging to the Old World clade of the alphavirus genus Togaviridae. As with other clinically impactful arboviruses, acute infection with CHIKV causes fever and severe joint pain. However, while CHIKV is not typically fatal it may lead to chronic and long-lasting arthralgic sequelae that can be debilitating $(1,2)$. Interhost transmission of CHIKV occurs via the bite of Aedes (subgenus Stegomyia) mosquito species. In regions where CHIKV is endemic, including tropical and subtropical areas of sub-Saharan Africa and Southeast Asia, two separate maintenance and transmission modes are evident. Enzootic cycles within nonhuman primate (NHP) species such as African green monkeys (Cercopithecus aethiops) and baboons (Papio ursinus) are believed to represent the evolutionarily ancestral maintenance pattern in forest and savannah (Tsetsarkin et al. 2016). Sporadic spillover of the virus into urban areas is thus likely to be the primary source of human CHIKV outbreaks (Diallo et al. 2012). While the sustained human-mosquito-human transmission is largely attributed to Aedes aegypti or Aedes albopictus species, the crucial factors that drive emergence into urban venues are not known. Nonetheless, the reality of ongoing enzootic transmission and periodic but unpredictable urban spillover means that in the absence of vector elimination strategies, human outbreaks will occur with regularity. Importantly, this also makes eradication of the virus by way of clinical, human host-administered treatments improbable. However, human populations could be rendered resistant to infection and thus limit spread through the generation of virus-specific immunity elicited by vaccination. While no CHIKV vaccines are currently approved for human use, many promising, safely efficacious, and novel vaccine platforms have been described including some that are currently in clinical trials.

While CHIKV-associated fatality rates are low, the economic impact of disease can be extreme and disproportionate between health systems and tiers of societal development. This includes the direct medical expenses associated with acute illness such as symptomatic treatment (de Brito et al. 2016) but also chronic inflammatory conditions which are more protracted and costly (Cardiel 2012). Perhaps more importantly, large indirect financial impacts result from acute and chronic CHIKV including illness-associated work absence, diminished productivity, and recurrent transportation to health providers. These indirect costs can be particularly high since many countries experiencing CHIKV outbreaks are underdeveloped and their economic capacities rely heavily on manual labor (Seyler et al. 2010). One analysis 
estimated that between 2013 and 2015 in the Americas $>23$ million disability-adjusted life years were lost leading to $>\$ 83$ billion in direct medical costs and $>\$ 101$ billion in indirect societal costs (Bloch 2017). In addition, regions susceptible to CHIKV transmission often represent destinations popular with tourists. In line with this, the 2005-2006 outbreak on the island of La Reunion led to an estimated loss of $\$ 160$ million in this industry (Enserink 2007). An efficacious vaccine would thus confer economic benefits in multiple ways including preventing incapacitation of labor forces, diminishing direct medical costs, and mitigating tourist uncertainty.

\section{CHIKV Replication and Immune Reactivity}

The CHIKV genome is approximately $11.8 \mathrm{~kb}$ single-stranded positive sense RNA that includes 5' and 3' untranslated regions (UTR), a 3' poly-A tail and 5' 7-methylguanosine cap [reviewed in (Vaney et al. 2013)]. Two open reading frames (ORFs) encode polyproteins separately comprised of four nonstructural (nsP1-4) and six structural (capsid [C], $6 \mathrm{~K}$, transframe [TF], envelope [E] 1, E2, E3) proteins. Infectious CHIKV exists as a $70 \mathrm{~nm}$ enveloped virion composed of 240 copies of E1 and E2 heterodimers in an icosahedral lattice configuration surrounding a nucleocapsid (Voss et al. 2010). E1 and E2 play essential molecular roles during initiation of replication that involve virion interaction with cellular receptors and internalization by clathrin-mediated endocytosis (Strauss and Strauss 1994). Following the release of the nucleocapsid into the cytoplasm, viral genomic RNA is translated to generate the nsP polyprotein, the proteolytic maturation of which gives rise to the RNA replicase [reviewed in (van Duijl-Richter et al. 2015)]. This is followed by the translation of the structural polyprotein from a subgenomic promoter at the terminus of the nsP coding region. Proteolysis of the structural proteins enables nucleocapsid interaction with genomic RNA, association with envelope glycoproteins at the plasma membrane, and budding of assembled particles.

Humoral and cellular adaptive immune processes are potently induced in response to $\mathrm{CHIKV}$ infection. Cell-mediated immunity is triggered and CD8+ and CD4+ T cells reactive to CHIKV antigens are known in humans (Hoarau et al. 2013), nonhuman primates (Messaoudi et al. 2013), and mice (Morrison et al. 2011; Teo et al. 2012a). The role for T cells in viral clearance, however, is not well understood and, in fact, may contribute to disease exacerbation (Teo et al. 2012a). In contrast, numerous studies have demonstrated the importance of antibodies with neutralization capacity for controlling CHIKV infection and tissue damage (Couderc et al. 2009; Sheela and Sumathy 2013; Lum et al. 2013; Hawman et al. 2013). IgM and IgG antibodies reactive to CHIKV appear early after symptom onset and IgG persists at high levels for years (Couderc et al. 2009; Kam et al. 2012a). Prior infection and development of anti-CHIKV neutralizing antibodies in humans associated with protection from re-infection (Yoon et al. 2015; Kam et al. 2012b; Galatas et al. 2016). In addition, passively transferred serum from 
convalescent humans protects mice from virus-associated lethality (Couderc et al. 2009). Intriguingly, CHIKV-reactive monoclonal antibodies have been isolated from patients that can also protect mice and even lead to diminished viremia and virus-associated disease in nonhuman primates (Smith et al. 2015; Broeckel et al. 2017). Longitudinal analysis in humans has identified the E2 and E3 glycoproteins as well as capsid and nsP3 as key targets of the antibody response (Kam et al. 2012a, c). However, the E2 protein appears to represent the immunodominant viral protein and antibodies reactive to it can confer broad-based viral neutralization (Kam et al. 2012c; Fox et al. 2015; Weger-Lucarelli et al. 2015). Surprisingly, no established minimum protective antibody titers have been described, although a reciprocal titer of approximately 35 was shown to be required in IFN-deficient mice, which presumably exhibit heightened susceptibility to the virus in comparison to humans (Chu et al. 2013).

Four main phylogenetic clades of CHIKV are recognized and include East/ Central/South African (ECSA), West African, Asian, and Indian Ocean lineages (IOL) that collectively share 84.5-97.8\% amino acid identity (Sahadeo et al. 2017; Volk et al. 2010). ECSA and Asian lineages are considered to be older and having evolved for transmission via $A$. aegypti. In recent years, however, adaptive mutations arose in the viral E1/E2 proteins of the IOL that likely facilitated interhost transmission by the more anthropophilic A. albopictus, a factor potentially playing a role in the virus' explosive global emergence (Tsetsarkin et al. 2007; Tsetsarkin and Weaver 2011). However, virus derived from the Asian lineage appears to be responsible for the emergence and local transmission in the Americas, which was first observed in 2013 (Lanciotti and Valadere 2014; Leparc-Goffart et al. 2014). While differences in virulence have been observed between viral lineages in mice (Wei Chiam et al. 2015; Teo et al. 2015) [especially those deficient in the type I interferon response with WA strains appearing more lethal (Langsjoen et al. 2018)] whether these or other differences are manifest in humans is not known. Interestingly, high CHIKV levels were detected in blood from healthy donors in Puerto Rico during an epidemic in 2014 that involved Asian/American lineages, suggesting that these strains may associate with higher rates of asymptomatic infection (Simmons et al. 2016). Importantly, from the standpoint of vaccination and control efforts, all CHIKV lineages comprise one serotype and cross-protection between strains is both observable and enduring in humans and other species (Langsjoen et al. 2018; Auerswald et al. 2018). Furthermore, antibodies reactive to CHIKV antigens may even confer protection against related Alphaviruses such as Ross River (Gardner et al. 2010) and O'nyong'nyong viruses (Partidos et al. 2012). However, despite this, variation has been reported in the neutralization efficiency of convalescent human sera across ECSA and Asian clades (Chua et al. 2016) suggesting that evaluation of such issues in vaccination efficacy studies is worthwhile. Nevertheless, vaccines that are, in general, antigenically focused are likely to protect against circulating lineages from all clinically relevant clades. 


\section{Animal Models of CHIKV Infection and Immunity}

Fortunately for the purposes of vaccine and therapeutic development, tractable animal models that faithfully recapitulate many aspects of human infection are available for examination of CHIKV replication, immunity, and pathogenesis [reviewed in (Haese et al. 2016)]. These have been instrumental for both investigating the safety and efficacy of novel vaccination platforms as well as characterizing the associated immune-mediated mechanisms. The most widely employed are wild-type and type I interferon (IFN) deficient mouse models (Taylor et al. 2015; Teo et al. 2012b). As experimental systems, these exhibit many desirable attributes including relatively low cost, ease of handling and care, ability to control environmental and genetic variables, and availability of reagents. They can also be utilized for studies of acute, chronic, and lethal CHIKV infection as well as virus-associated inflammatory dysfunction (Morrison et al. 2011; Hawman et al. 2013; Ziegler et al. 2008; Couderc et al. 2008a; Poo et al. 2014). In particular, lack of type I IFN-dependent antiviral phenotypes renders animals fully susceptible to CHIKV-induced mortality (Couderc et al. 2008b; Rudd et al. 2012; Gardner et al. 2012), and, as such, this represents a highly stringent model for exploring the potency of antibodies and $\mathrm{T}$ cells generated by vaccination or following inter-animal transfer (Smith et al. 2015; Plante et al. 2011; Pal et al. 2013). Furthermore, many fundamental innate and adaptive immunologic processes involved in CHIKV protection and clearance are shared between humans and mice. As such they represent a powerful and cost-effective first-pass testing platform for characterization and mechanistic understanding of novel vaccine technologies. Informative nonhuman primate (NHP) models of CHIKV infection and immunity have also been developed and are commonly used, including Cynomolgus (Chen et al. 2010; Messaoudi et al. 2013) and Rhesus (Chen et al. 2010; Messaoudi et al. 2013) macaque species. NHP models exhibit advantages over murine models that make them more translatable to humans such as increased susceptibility to infection, outbred genetic structure, and maternal/fetal transmission. In addition, NHP models are considered more representative of human vaccine responses owing to their size, distribution of immune cell subsets, innate immune receptor expression, and the morphology of injection site and lymphatic systems [reviewed in (Thompson and Loré 2017)]. However, their expense and requirement for highly specialized housing render NHP models more applicable to studies examining vaccine technologies for which a more comprehensive proof of principle has been established.

\section{Vaccine Technology Classes}

Given the importance of humoral immunity for controlling infection, ongoing vaccine development efforts are primarily focused on eliciting antibody-dependent responses for protection against $\mathrm{CHIKV}$. To accomplish this, five general technological platforms have been or are being explored. These include live attenuated 
chikungunya viral (LAV) strains, chimeric viral vectors, inactivated virions or virus-like particles (VLP), subunit vaccines, and DNA plasmid. Each has displayed efficacy in animal models and some are even immunogenic in humans. A LAV for CHIKV involves limited intrahost replication and has proven particularly capable of eliciting neutralizing antibody production in humans (Edelman et al. 2000). However, as a class, such vaccines are often associated with suboptimal safety profiles owing mostly to their unlikely but demonstrated the potential for reversion to a pathogenic viral state. As such they are contraindicated in hosts with weakened or immature immune systems including the elderly, neonates, and those undergoing strategic immunosuppression. This has necessitated the development of novel immunogen delivery platforms that do not involve viral growth within vaccinees. Moreover, while direct administration of inert viral antigen or molecular platforms that involve the synthesis of such antigen in vivo are safer, these often lead to weaker, shorter lived immunity since they stimulate fewer facets of the immune response in a localized, rather than disseminated manner. As such they often require co-delivery of nonantigenic molecules termed adjuvants that act by stimulating localized innate immune processes to enhance immunogenicity [reviewed in (Reed et al. 2013; Coffman et al. 2010)]. Alternatively, recombinant heterologous viral platforms that encode and express CHIKV antigen but are incapable of growth in vivo represent another safe and powerful method for eliciting protective immunity [reviewed in (Ramsauer and Tangy 2016)]. Diverse efforts pursuing these and other technologies are currently the subject of substantial research investment to identify an optimal method of immune protection against CHIKV.

\subsection{Live Attenuated Viral Vaccines}

The earliest CHIKV vaccine to successfully demonstrate protective immunostimulation in humans involved a clinical strain from Thailand that was sequentially passaged multiple times on human MRC5 human lung fibroblasts and designated 181/clone 25 (Levitt et al. 1986). In clinical trials, the vaccine was highly immunogenic with all but one out of 59 adults generating neutralizing antibody titers (Edelman et al. 2000). However, 10\% of recipients experienced mild arthralgia. It was subsequently determined that only two amino acid changes were responsible for the pathogenic differences between the clinical and the attenuated vaccine strain, making the likelihood of reversion unacceptably high for clinical use (Gorchakov et al. 2012). Other efforts to construct LAV have involved modifying targeted genomic regions to impair viral growth. This is greatly facilitated by utilizing infectious cDNA clones for viral reconstitution, the mutation of which is straightforward by standard molecular methods (Vanlandingham et al. 2005; Tsetsarkin et al. 2006). For instance, CHIKV-containing deletions in open reading frames that encode $\mathrm{nsP} 3,6 \mathrm{~K}$, or $\mathrm{E} 2$ have each been shown to be replication incompetent in vivo yet capable of eliciting protective antibody responses in mice (Hallengärd et al. 2014; Piper et al. 2013; Gardner et al. 2014). The most promising 
implementation of this approach is the $\Delta 5 \mathrm{nsP} 3$-attenuated virus from the laboratory of Peter Liljestrom that contains a 60 amino acid deletion of the nsP3 protein (Hallengärd et al. 2014). This attenuation strategy allows for sufficient in vitro replication but no viremia after inoculation of mice with a dose sufficient to elicit neutralizing antibody titers and antiviral $\mathrm{T}$ cell responses and block detectable viremia. This vaccine has proved to be similarly efficacious in a cynomolgus macaque viral immunogenicity and challenge model (Roques et al. 2017). Importantly, a phase I clinical trial using this platform (identifier NCT03382964) that involved 120 participants was very recently completed by Valneva and showed a superior safety profile and seroconversion in all vaccinees at day 14 after a single dose.

A rational attenuation method devised by Scott Weaver and colleagues involves replacing the endogenous subgenomic viral promoter region responsible for driving normal expression of antigenic structural proteins with a picornavirus internal ribosomal entry site (IRES), leading to diminished protein synthesis (Chu et al. 2013; Langsjoen et al. 2018; Partidos et al. 2012; Plante et al. 2011, 2015; Roy et al. 2014; Kim et al. 2011). The resulting virus grows slowly in vitro, is fully attenuated in vivo, and does not replicate in mosquito cells so it cannot be conventionally transmitted between hosts. Importantly, given the size and complexity of the modified genomic region, reversion mutations are quite improbable making it a presumably safe treatment. This vaccine effectively generates protective antibody responses in both wild-type and IFN-deficient mice as well as NHP without adverse effects. While conventional $\mathrm{T}$ cell activation appears to be triggered by the vaccine, adoptive transfer of $\mathrm{CD} 4+$ or $\mathrm{CD} 8+$ cells to mice following vaccination did not protect against challenge; an additional indication that cellular immunity is of limited relevance during CHIKV infection. Moreover, the vaccine's efficacy in immunocompromised animals further predicts its safety for immune-insufficient patients. This vaccine was also found to elicit protective immunity against the antigenically related Alphavirus O'nyong'nyong virus (ONNV) in IFN-deficient mice and dams receiving the vaccine vertically transferred antibody-mediated protection to their offspring. This platform is currently being developed commercially by a partnership between Takeda Pharmaceuticals and Zydus Cadila.

\subsection{Chimeric Viral Vector Platforms}

Another impactful vaccination approach being actively explored involves the delivery of CHIKV antigen using heterologous viral vectors [reviewed in (Ramsauer and Tangy 2016)]. This includes the construction of chimeric virus particles containing CHIKV genomic regions encoding antigenic proteins that enter cells in vivo but either do not generate progeny or only undergo a single round of replication. Their limited viability renders them unlikely to confer pathogenic or reactogenic effects. Virus types co-opted for this purpose include both RNA- and DNA-based agents, including related Alphaviruses. Moreover, depending on the 
platform they are also able to elicit both humoral and cell-mediated immune responses especially since, by utilizing cellular protein synthesis and processing pathways, they lead to antigen presentation via MHC class I and subsequent $\mathrm{T}$ cell activation (Liu 2010). Being structurally complete viruses, these vectors are also likely to be comprised of molecular patterns that activate pattern recognition receptors and thus enhance immunogenicity through innate immune stimulation (Hu and Shu 2018; Iwasaki and Medzhitov 2015). While preexisting immunity against some common human viruses can lead to diminished efficacy of vectors on which they are based (Saxena et al. 2013), solutions appear to be obtainable including utilizing nonhuman virus types or antigenically modifying human viruses. As with LAV, chimeric viruses must be maintained and administered in a manner that permits viability as determined by cellular fusion and genome delivery. As such, both technologies can require specialized manufacturing, storage, and transport procedures that are not always feasible with application in underdeveloped areas (Ulmer et al. 2006; Lloyd and Cheyne 2017).

The earliest chimeric vaccines against CHIKV involved vectors that encode the nonstructural proteins of other related alphavirus species including Sindbis virus (SINV), Eastern equine encephalitis virus (EEEV), or an attenuated strain (TC-83) of Venezuelan equine encephalitis virus (VEEV) with the structural proteins of CHIKV (Wang et al. 2008, 2011a). This allowed generation of virus particles that grow to high titer in cell culture but do not replicate in vivo, indicative of appropriate safety. Intriguingly, the VEEV- and EEEV-based vectors also elicited neutralizing antibody titers in vaccinated mice and led to protection from viremia and virus-associated mortality and disease in these animals. VEEV-based vectors were additionally modified by the introduction of IRES elements to drive structural protein synthesis, further improving their safety, rendering them effective in IFN-deficient mice, and preventing their mosquito transmissibility.

Vesicular stomatitis virus (VSV) represents another RNA-based virus that can be engineered using simple methods and exploited for heterologous vaccination purposes (Roberts et al. 1999). VSV is a negative-stranded RNA member of the Rhabdoviridae family whose envelope can be pseudotyped with glycoproteins derived from unrelated viruses to enhance immunogenicity and alter cellular tropism. In addition, VSV-based vectors are able to elicit potent CD8+ T cell responses against target antigens (Haglund et al. 2002) and have been successfully employed in the context of diverse viral and bacterial pathogens. Chattopadhyay and colleagues have constructed chimeric VSV in which the endogenous glycoprotein $\mathrm{G}$ coding region is replaced by $\mathrm{CHIKV}$ structural proteins (Chattopadhyay et al. 2012). This yields virions into which antigenic CHIKV envelope glycoproteins are incorporated but that also enables cellular entry and new intracellular synthesis of these antigens following inoculation. The vector was shown in mice to elicit both neutralizing antibody and cellular immune responses against CHIKV and protection against viremia and CHIKV-associated disease. Whether CHIKV-directed vaccines that incorporate this platform operate safely in NHP models or humans still requires examination but currently a VSV-based vaccine against Ebola virus is undergoing phase III clinical trials (Coller et al. 2017). 
One particularly novel chimeric virus vaccine was recently described by Erasmus and colleagues that involves Eilat virus (EILV), an alphavirus specific to insect species (Erasmus et al. 2015, 2016). The virus is incapable of replication in mammals due to an inability to enter cells or form nonstructural protein-mediated replication complexes (Nasar et al. 2015). Based on this, it was predicted that chimeric genomes consisting of the EILV 5'UTR and nonstructural polyprotein and CHIKV structural polyprotein would yield antigenic virus particles when introduced into mosquito cells. Furthermore, despite containing intact genomes and CHIKV virion proteins, the virus should not be capable of generating a replication competent, and thus pathogenic, particles in vivo since the nsPs do not function in mammalian cells. Moreover, the lack of viral RNA transcription also precludes the emergence of replication-viable mutants. Remarkably, a single dose of the vaccine was shown to elicit neutralizing antibodies and protection against viral challenge in WT and IFN-deficient mice as well as NHP. While the vaccine's efficacy has not been comparatively evaluated relative to other viral-vectored or VLP-based platforms, it may involve an enhanced mechanism of antigen presentation by entering cells via the endocytic pathway (Erasmus et al. 2016). In addition, the presence of genomic RNA in the viral particle may provoke innate immune reactivity and thus adjuvant-like properties (Vasilakos and Tomai 2013). As such, EILV may represent a powerful vaccine platform for CHIKV and other viruses that warrants thorough exploration.

DNA-based viruses have also been shown to be effective as vectors for vaccine antigen delivery and immunostimulation. This includes adenoviruses and the poxvirus modified vaccinia virus Ankara (MVA) (Volz and Sutter 2017; Majhen et al. 2014). Non-replicating adenovirus vectors have been well-studied for use in both gene therapy and vaccination and this includes hundreds of clinical trials. As such, ample evidence of their safety and efficacy has been amassed. The complex adenovirus 5 (Ad5) vaccine vectors contain deletions of regions essential for replication that can be complemented in transgenic cell lines to allow particle formation. These are amenable to accepting large user-defined insertions and have been effectively employed as vaccines against viral pathogens including influenza, Ebola, Dengue, West Nile, and Rift Valley fever viruses. Wang and colleagues used this platform to deliver CHIKV envelope glycoproteins and capsid to CD-1 and C57BL/6 mice (Wang et al. 2011b). They show that the vaccine elicits antibody titers as high as those generated by natural infection and confers complete protection against viral challenge. Additionally, adenoviruses of nonhuman species also represent potentially safe and efficacious vaccine vectors that circumvent any impacts of preexisting immunity in recipients. This is currently being employed in clinical trials using Chimpanzee adenovirus expressing CHIKV structural proteins (identifier NCT03590392) (Ewer et al. 2017).

MVA is derived from vaccinia virus smallpox vaccine following 570 passages in avian tissue culture, which caused large genomic deletions that abrogate productive replication in many species including humans (Moss et al. 1996). MVA also supports stable introduction and expression of heterologous antigenic proteins for which it has been effectively utilized to stimulate immunity against viral, bacterial, 
and parasitic pathogens. Importantly, MVA also leads to the generation of both humoral and cell-mediated protective immunity (Draper et al. 2013). In 2014, three separate groups reported the synthesis and assessment of MVA-vectored vaccines against CHIKV. Van den Doel and colleagues constructed a vector that expresses CHIKV 6K-E1-E3-E2 polyprotein and fully protects IFN-deficient A129 mice from CHIKV-induced lethality without adverse effects (van den Doel et al. 2014). Weger-Lucarelli and colleagues similarly generated MVA that expresses only E2E3 (Weger-Lucarelli et al. 2014). This also protected A129 mice from lethal CHIKV challenge. Interestingly, however, sera from mice vaccinated with this vector failed to protect nonvaccinated A129 mice from CHIKV mortality following the passive transfer. Moreover, depletion of CD4+, but not CD8+ cells from vaccinated mice prevented MVA-mediated protection, suggestive of a role for cell-mediated immunity in this outcome. Finally, Garcia-Arriaza and colleagues inserted the entire CHIKV structural polyprotein (C-E3-E2-6K-E1) into MVA and demonstrated strong innate immune induction following the vector's administration, consistent with that observed during conventional viral infection or injection of adjuvanted vaccines (discussed below) (García-Arriaza et al. 2014). This vector clearly elicited a broad, polyfunctional $\mathrm{T}$ cell response as well as neutralizing antibodies and protection against viremia in C57BL/6 mice. Currently, both adenovirus and MVA-based CHIKV vaccines are in a preclinical stage of development and NHP studies would greatly enhance our evaluation of their translatability to humans. Importantly, however, these platforms also represent important research tools that can lead to useful mechanistic insight regarding the respective roles of humoral and cell-mediated immune processes for protection against CHIKV and the development of CHIKV-associated disease.

The most clinically advanced chimeric platform for CHIKV immunization involves the Measles virus (MV) Schwarz attenuated vaccine strain as a delivery vector [reviewed in (Tangy and Naim 2005)]. MV is a negative-stranded RNA virus for which a cDNA plasmid-based reverse genetic system has been optimized that allows expression of heterologous protein antigens (Combredet et al. 2003). MV/ Schwarz is an extremely safe, efficacious, and historically utilized vaccine that confers lifelong protective immunity following a single immunization. Furthermore, it has been effectively adapted for the generation of protective responses against viral pathogens such as West Nile, dengue, HIV, and SARS coronavirus [reviewed in (Mühlebach 2017)]. For purposes of practical investigation and clinical translatability, the MV platform exhibits important advantages. First, transgenic mouse models have been constructed to be susceptible to MV infection through the introduction of the viral receptor CD46 in the presence and absence of a functional IFN response for added stringency (Combredet et al. 2003). Next, NHP are also infectible with MV and immune reactivity to encoded antigens occurs in the following exposure (de Swart and DeSwart 2009). Finally, preexisting immunity to MV in vaccines does not appear to impact heterologous immunogenicity elicited by the vector in animals or humans (Reisinger et al. 2019).

Frederic Tangy's research group has elegantly leveraged this technology to synthesize a safe and immunogenic CHIKV vaccine (Brandler et al. 2013; 
Ramsauer et al. 2015). Specifically, MV/Schwarz genomes have been constructed that contain the full CHIKV structural polyprotein that replicates to high titer in vitro and confers potent antibody-mediated protective immunity against multiple clades of CHIKV in IFN-deficient mice as well as cynomolgus macaques (Rossi et al. 2019). Importantly, this vaccine has also completed phase II clinical trials (identifiers NCT03101111, NCT02861586) clinical trials to demonstrate safety, tolerability, and immunogenicity (Reisinger et al. 2019). In the first trial, 36 subjects received one of three MV-CHIKV doses and were boosted after either 1 or 3 months. Single immunization led to detectable neutralizing antibody titers for all doses. However, full seroconversion was achieved in all vaccine groups after the booster immunization, preexisting anti-MV antibodies did not affect the immune response, and the vaccine displayed acceptable tolerability. The second trial involved 236 participants that received control MV $(\mathrm{n}=34), \mathrm{MV}-\mathrm{CHIK}(\mathrm{n}=195)$, or MV control and MV-CHIK ( $\mathrm{n}=34)$. This study demonstrated seroconversion of $50-93 \%$ of participants after a single MV-CHIK dose and $86-100 \%$ of participants after MV-CHIK boost. Moreover, antibody titers were positively correlated with vaccine dose and preexisting immunity to $\mathrm{MV}$ did not affect reactivity to MV-CHIK. It is important to note that the precise MV-CHIKV mechanism of action is not defined. However, cells infected in vitro with the virus are known to synthesize and release virus-like particles (VLP) that are likely to be immunogenic (Brandler et al. 2013) (discussed in more detail below). It is possible that these are taken up and trafficked to lymph nodes by antigen presenting cells to initiate immune responses. Currently, this vaccine is being commercially developed by Themis Bioscience.

\subsection{Inert Antigen Vaccines}

In contrast to vaccine platforms that involve molecular synthetic processes during virus-based antigen delivery, others exist that are comprised of inactivated or genome-deficient viral particles or individual purified viral proteins. Given the spectrum of immunocompetence present in the human population, these are generally considered safer than LAV and chimeric virus vectors since they do not undergo any in vivo molecular replication. However, the antigenicity of these may be suboptimal since conformation of native epitopes can be susceptible to damage in response to the inactivation and purification processes. In addition, these are administered locally and without regional amplification or systemic immune activation. As such, inert virus particle-based vaccines exhibit lower immunogenicity and can require booster immunizations as well as the inclusion of adjuvants to stimulate innate immune processes and enhance antigen processing and delivery. Multiple methods have been utilized to inactivate live CHIKV particles in a manner that aims to maintain their immunogenic capacity. This includes treatment with chemicals such as binary ethyleneimine (Gardner et al. 2010), $\beta$-propiolactone (Kumar et al. 2012), Tween 80/ether (Eckels et al. 1970), and formalin 
(Tiwari et al. 2009) or exposure to UV-irradiation (Nakao and Hotta 1973). These have been examined in preclinical mouse or NHP models and proved to generate protective virus-directed antibody responses, in some cases even without adjuvant. Formalin-inactivated CHIKV has also been used in human volunteers without adjuvants and shown to tolerably elicit antibodies with neutralization capacity (Harrison et al. 1971). Unfortunately, inactivation of live clinical strains of CHIKV requires biosafety level 3 conditions for production. This renders the process costly and difficult to scale-up and thus only feasible for experimental work.

Antigenic fidelity of CHIKV proteins for efficacious vaccine-mediated immunostimulation can also be readily achieved through synthesis and purification of virus-like particles (VLP). These are comprised of self-assembling viral structural proteins that conformationally resemble wild-type virions but contain no genomic material and thus cannot initiate replication [reviewed in (Mohsen et al. 2017)]. The safety profile of VLPs is thus heightened over inactivated, live attenuated, or chimeric viruses since viral growth is not possible in any step of the production or vaccination process. In addition, biosafety requirements for manufacturing are also less stringent and thus scale-up is more technically feasible and cost-effective. Generation of virion-based antigens on mammalian or insect (Metz et al. 2013a) cells additionally benefits from proper protein folding, glycosylation, and post-translational modifications important for epitope structure. Currently, several licensed VLP-based vaccines are in widespread clinical use against human papillomavirus, hepatitis $\mathrm{B}$, and hepatitis $\mathrm{E}$ viruses. In the case of $\mathrm{CHIKV}$, ectopic translation of the viral envelope polyprotein (E2-E2-6K-E1) in cultured cell lines following transfection or transduction of expression vectors leads to the secretion of particles that are similar in size, structure, and protein configuration to the native virus (Akahata et al. 2010; Sun et al. 2013). These can then be isolated, purified, and concentrated from cell culture media by ultracentrifugation or filtration for direct in vivo administration. Importantly, human cell lines amenable to CHIKV VLP synthesis have been approved for vaccine production by regulatory agencies and thus tractable methods of clinic-ready scale-up are available (Genzel 2015).

Studies have demonstrated that immunization with VLP synthesized using mammalian or insect cells elicit protective antibody responses in wild-type and an IFN-deficient mouse models as well as in NHP (Metz et al. 2013a, b; Akahata et al. 2010). Importantly, a VLP-based vaccine manufactured using characterized and FDA-approved HEK293 cells by the NIH Vaccine Research Center has completed a phase I clinical trial (identifier NCT01489358) (Chang et al. 2014) and phase II trials in the Caribbean (identifier NCT03483961, NCT02562482) are currently ongoing. The completed phase I study involved 23 participants receiving one of three doses at 0 , 4 , and 20 days by intramuscular injection. The vaccine was well tolerated and, crucially, led to the production of neutralizing antibodies after the first boost in a manner weakly associated with antigen dose for all participants. Titers were maintained for at least 6 months and were at levels likely to be protective based on observations from convalescent sera (Kam et al. 2012a, b). Moreover, the neutralization capacity of sera collected from participants was shown to exist against nine viral strains comprising three clades, suggesting that vaccination against one strain can elicit cross-protection 
(Goo et al. 2016). Interestingly, while published animal studies have employed CHIK VLP admixed with innate stimulating adjuvants, the clinical trial actually observed neutralizing antibodies in their absence. Whether adjuvants are not necessary or, rather, could actually enhance protective immune responses to a degree that allows dose sparing or single administration will necessitate further exploration. The duration that protective antibody titers are measurable following vaccination also requires investigation and this may also warrant the inclusion of adjuvants.

Individual recombinant CHIKV envelope proteins have also been effectively utilized as a vaccine antigen. Immunization with single proteins offers advantages such as ease and simplicity of synthesis and adaptability to strain variation if needed. Bacterial expression systems were used to synthesize and purify E1 and E2 proteins (Kumar et al. 2012; Khan et al. 2012). Administration of these proteins to WT mice elicited neutralizing antibodies in WT mice as well as protection from viremia, viral dissemination, and virus-mediated disease. However, recombinant peptides alone appear to be poorly immunogenic and require adjuvant admixture. Multiple classes of adjuvants were shown to enhance the E1- and E2-associated immune response. In addition, vaccination with E1/E2 subunits is also capable of generating balanced Th1/Th2 polarization as indicated by high titers of IgG1, $\operatorname{IgG} 2 \mathrm{c}$, and $\mathrm{IgG} 3$ antibody subclasses. The efficacy of subunit vaccination has yet to be examined in IFN-deficient mice or non-murine models.

\subsection{Nucleic Acid Based Vaccines}

Another approach to CHIKV vaccination involves the utilization of plasmid DNA that encodes immunogenic or protective factors that prevent infection. Direct delivery, often involving intracellular electroporation, into receptive tissues of DNA vectors can lead to in situ synthesis of user-specified proteins. This technology exhibits many logistical and biological advantages including stimulation of both humoral and cell-mediated immune responses, low production cost, high vaccine stability (cold chain independence), ease of manufacturing, capacity for co-delivery of multiple antigens, and capacity for rapid customization in the event of spontaneous strain emergence. Moreover, only basic molecular cloning methods are needed for synthesizing and adapting vectors of interest, greatly facilitating the experimental investigation. Muthumani and colleagues described the first DNA-based vaccine vector for CHIKV (Muthumani et al. 2008). The authors designed consensus E1, E2, and capsid proteins based on multiple sequences derived from clinical isolates across years of outbreaks and cloned the respective coding regions into a DNA expression vector. Intramuscular electroporation was used to deliver the constructs to mice and shown to elicit both CHIKV-reactive antibodies and IFN $\gamma$-producing $\mathrm{T}$ cells in response to CHIKV antigen. Follow up work by this group included the construction of an E1, E2, and E3 expressing vector that led to similar immune induction as well as protection against viral 
challenge in mice (Mallilankaraman et al. 2011). Additionally, this vector was also able to induce neutralizing antibody and $\mathrm{T}$ cell responses following administration to NHP indicating that it is operational across species. A similar approach that has also been used involves the introduction to DNA vectors of CHIKV-derived genomic regions that allow the in vivo synthesis and secretion of immunogenic VLP (Hallengärd et al. 2014; Hallengard et al. 2014) or the LAV strain 181/25 (Tretyakova et al. 2014). Both methods led to the production of neutralizing antibody responses in mice and while protection against $\mathrm{CHIKV}$ challenge was not checked for the LAV, it was observed for the VLP as indicated by the absence of viremia and CHIKV-associated disease. An antigen-independent DNA vector-based approach has also been used to successfully elicit prophylactic immunity to CHIKV infection in a manner that is more rapid than traditional vaccination. This involves the DNA encoding of an envelope-reactive monoclonal antibody sequence with broadly neutralizing capacity (Muthumani et al. 2016). In vivo delivery of this vector led to the synthesis of detectable CHIKV-reactive antibodies after three days and peak titers were observed by day 15-21. Remarkably, this vector conferred protection against CHIKV when administered as early as two or as late as thirty days pre-challenge. While DNA-based vaccines hold much promise, additional mechanistic and efficacy studies will be needed to fully elucidate their potential clinical applicability.

In addition to antigenic CHIKV proteins being encoded by DNA, they may also be expressed in vivo directly from messenger RNA (mRNA). The susceptibility of RNA to degradation leads to more stringent delivery requirements that protect the molecule such as lipid nanoparticle formulations. This approach has been used to deliver liposomal mRNA that encodes a highly potent neutralizing antibody identified from a B cell clone of a convalescent patient. This has led to vaccine dose-associated protection of IFN-deficient mice from lethal CHIKV challenge (Kose et al. 2019). Furthermore, administration of this platform in WT mice also led to substantial reduction or prevention of CHIKV viremia and viral RNA tissue loads and its use in cynomolgus macaques led to detectable serum levels of encoded IgG. Finally, mRNA encoding CHIKV antigens has proven capable of eliciting neutralizing antibodies in human subjects (Shaw et al. 2019). A phase I clinical trial using this vaccine is currently ongoing under the direction of Moderna, Inc. (identifier NCT03325075).

\section{Priorities for and Barriers to Clinical CHIKV Vaccine Development}

As outlined above and summarized in Table 1, numerous vaccine technologies have been shown to safely and efficaciously elicit protection in animal and human models against CHIKV infection and disease. A number of these platforms have even obtained regulatory approval for use against other pathogens. In addition, 


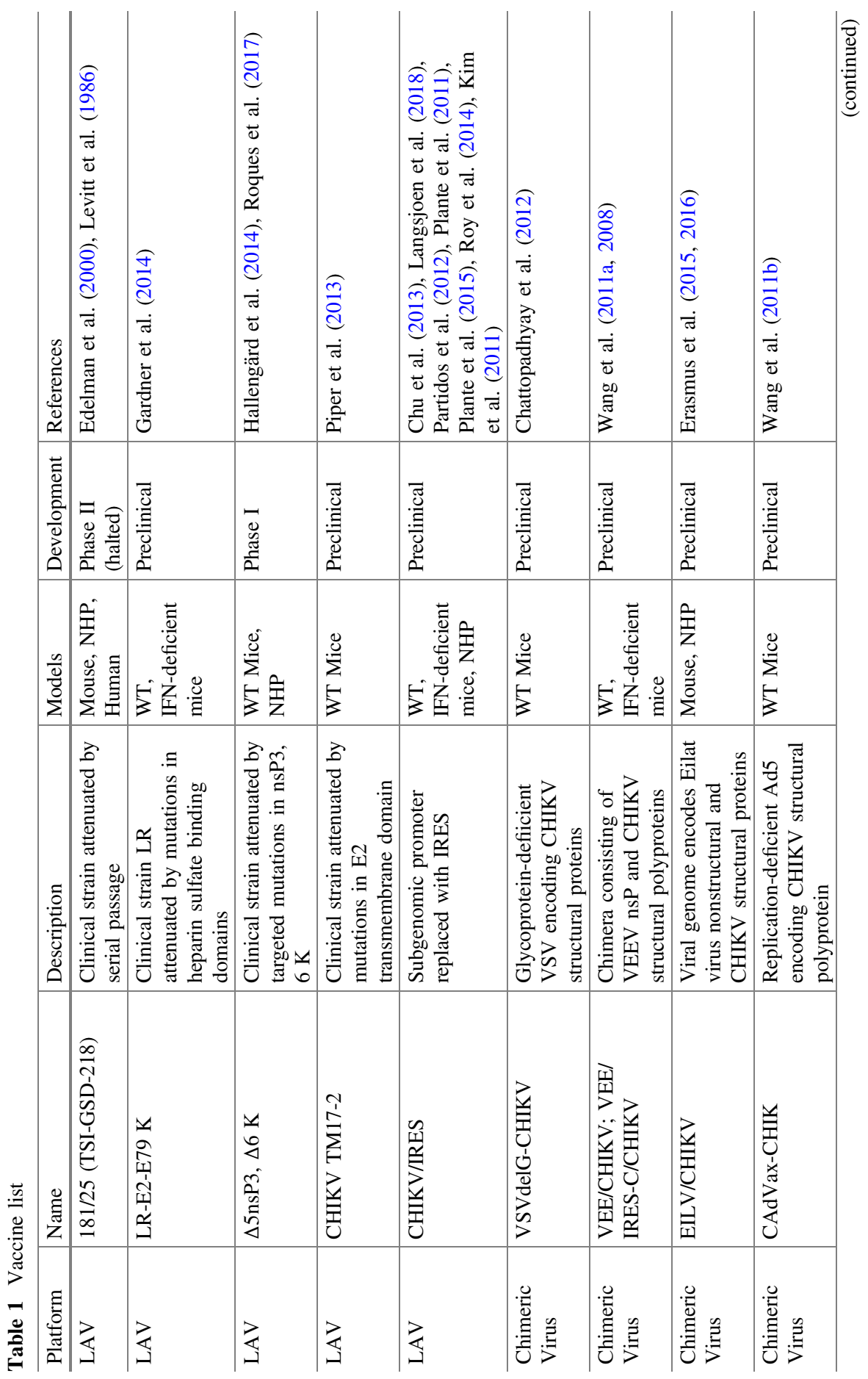




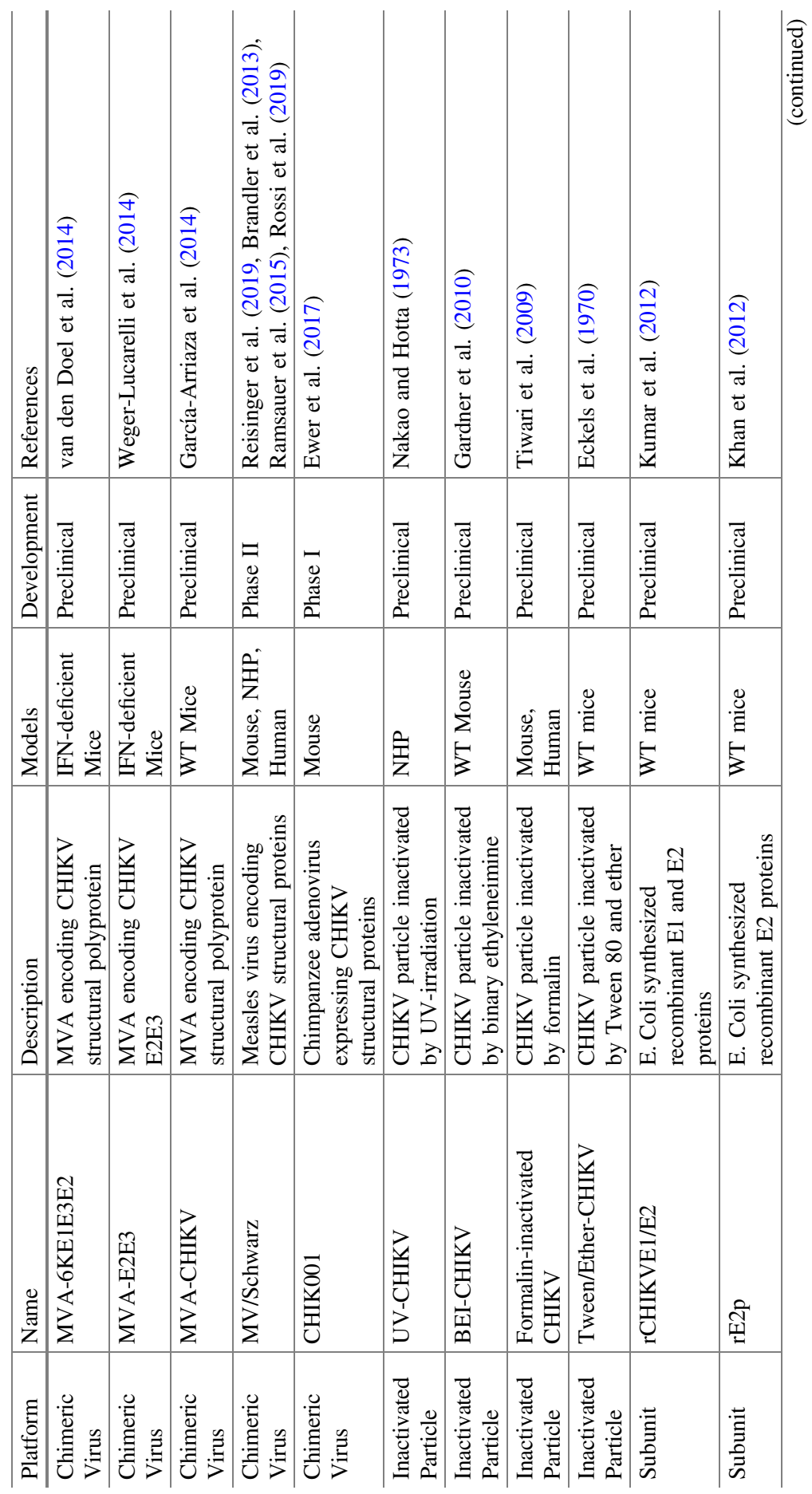




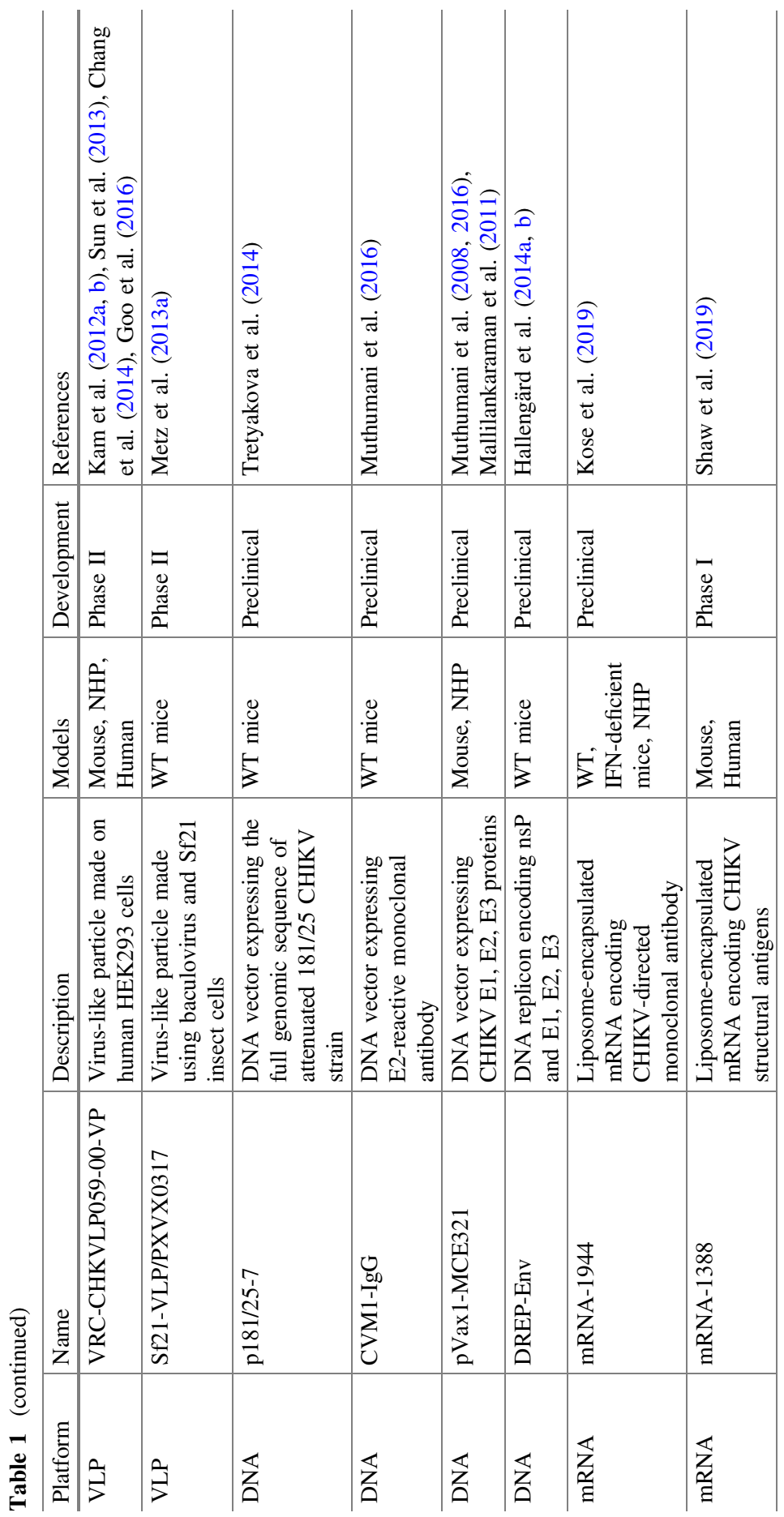


clinical trials have also been completed or are currently underway for some technologies. However, despite this, regulatory bodies are yet to approve the widespread commercial utilization of any vaccine against CHIKV in humans. Unfortunately, the financial cost of developing a vaccine ready for distribution in human populations is on the order of hundreds of millions of dollars and thus requires a substantial commitment from private, nonprofit, or public institutions. As such, it will be necessary that threshold levels of either commercial potential or public need are crossed and associated with suitable risk criteria in order to attract the resources necessary for bringing a CHIKV vaccine into clinical use. Given that the burden of the virus is disproportionately incurred by economically developing nations, market forces may not forecast a return on investment necessary to incentivize for-profit entities in this endeavor. Moreover, the focal and episodic nature of CHIKV outbreaks, as well as establishment of herd immunity, renders phase III efficacy trials logistically problematic. However, spontaneous and unforeseen factors that drive arbovirus emergence and spread may fluctuate in a manner that results in outbreaks of magnitude or that shift geographically such that expanded market potential is revealed. Additionally, a market may also exist among travelers from developed countries interested in obtaining immune protection prior to the visitation of afflicted areas. Military needs may also drive vaccine development and thus government(s) may fund clinical advancement in the absence of commercial demand. The Global Alliance for Vaccines and Immunization (GAVI) also financially supports efforts in low-to middle-income countries to develop vaccines based primarily on disease burden and overall program sustainability.

Priority populations in which enhanced susceptibility to or severity of CHIKV-induced disease are evident include neonates (Charlier et al. 2017) and the aged (Lang et al. 2017; Godaert et al. 2017). As such, vaccine platforms pursued clinical use need to account for the immature or senescent immune status of these groups. Specifically, this includes an enhanced safety profile (including reactogenicity, adverse effects, and vaccine-induced disease) and appropriate immunostimulatory capacity. As discussed above, LAV are considered less safe due to the possibility of reversion or enhanced replication in the absence of robust immunity. Subunit and VLP-based vaccines exhibit improved safety profiles but are clearly less immunogenic. However, adjuvant classes and combinations exist and are being actively pursued that are capable of addressing this (Bonam et al. 2017; Aspinall et al. 2007; Levy et al. 2013; Borriello et al. 2017). Importantly, clinical trials examining vaccine safety and efficacy should be designed and executed in accordance with these goals. In addition, the establishment of a standard antibody neutralization protocol and criteria that can be applied to allow comparison across studies will also be crucial for further development. Finally, prioritization of a CHIKV vaccine will also depend on the emergence and outbreaks of other viral diseases such as Zika and Ebola or unknown zoonotic agents. These impose their own unique burdens on human populations and independently attract attention, effort, and investment. 


\section{References}

Akahata W, Yang Z-Y, Andersen H, Sun S, Holdaway HA, Kong W-P, Lewis MG, Higgs S, Rossmann MG, Rao S, Nabel GJ (2010) A virus-like particle vaccine for epidemic Chikungunya virus protects nonhuman primates against infection. Nature Medicine 16:334-338

Aspinall R, Del Giudice G, Effros RB, Grubeck-Loebenstein B, Sambhara S (2007) Challenges for vaccination in the elderly. Immun Ageing 4:9

Auerswald H, Boussioux C, In S, Mao S, Ong S, Huy R, Leang R, Chan M, Duong V, Ly S, Tarantola A, Dussart P (2018) Broad and long-lasting immune protection against various Chikungunya genotypes demonstrated by participants in a cross-sectional study in a Cambodian rural community. Emerg Microbes Infect 7:13

Bloch D (2017) The Cost and burden of Chikungunya in the Americas 1-34

Bonam SR, Partidos CD, Halmuthur SKM, Muller S (2017) An overview of novel adjuvants designed for improving vaccine efficacy. Trends Pharmacol Sci 38:771-793

Borriello F, Pietrasanta C, Lai JCY, Walsh LM, Sharma P, O'Driscoll DN, Ramirez J, Brightman S, Pugni L, Mosca F, Burkhart DJ, Dowling DJ, Levy O (2017) Identification and characterization of stimulator of interferon genes as a robust adjuvant target for early life immunization. Front Immunol 8:1772

Brandler S, Ruffié C, Combredet C, Brault J-B, Najburg V, Prevost M-C, Habel A, Tauber E, Desprès P, Tangy F (2013) A recombinant measles vaccine expressing Chikungunya virus-like particles is strongly immunogenic and protects mice from lethal challenge with Chikungunya virus. Vaccine 31:3718-3725

Broeckel R, Fox JM, Haese N, Kreklywich CN, Sukulpovi-Petty S, Legasse A, Smith PP, Denton M, Corvey C, Krishnan S, Colgin LMA, Ducore RM, Lewis AD, Axthelm MK, Mandron M, Cortez P, Rothblatt J, Rao E, Focken I, Carter K, Sapparapau G, Crowe JE, Diamond MS, Streblow DN (2017) Therapeutic administration of a recombinant human monoclonal antibody reduces the severity of Chikungunya virus disease in rhesus macaques. PLoS Negl Trop Dis 11:e0005637

Cardiel MH, Pons-Estel BA, Sacnun MP, Wojdyla D, Saurit V, Marcos JC, Pinto MRC, Cordeiro de Azevedo AB, da Silveira IG, Radominski SC, Ximenes AC, Massardo L, Ballesteros F, Rojas-Villarraga A, Oñate RV, Hernandez MP, Esquivel-Valerio JA, García-De La Torre I, Khoury VJ, Millán A, Soriano ER, GLADAR (2012) Treatment of early rheumatoid arthritis in a multinational inception cohort of Latin American patients: the GLADAR experience. J Clin Rheumatol 18:327-335

Chang L-J, Dowd KA, Mendoza FH, Sounders JG, Sitar S, Plummer SH, Yamshchikov G, Sarwar UN, Hu Z, Enama ME, Bailer RT, Koup RA, Schwartz RM, Akahata W, Nabel GJ, Mascola JR, Pierson TC, Graham BS, Ledgerwood JE, Team TV3S (2014) Safety and tolerability of Chikungunya virus-like particle vaccine in healthy adults: a phase 1 dose-escalation trial. The Lancet 384:2046-2052

Charlier C, Beaudoin M-C, Couderc T, Lortholary O, Lecuit M (2017) Arboviruses and pregnancy: maternal, fetal, and neonatal effects. Lancet Child Adolesc Health 1:134-146

Chattopadhyay A, Wang E, Seymour R, Weaver SC, Rose JK (2012) A chimeric vesiculo/ alphavirus is an effective Alphavirus Vaccine. J Virol

Chen C-I, Clark DC, Pesavento P, Lerche NW, Luciw PA, Reisen WK, Brault AC (2010) Comparative pathogenesis of epidemic and enzootic Chikungunya viruses in a pregnant Rhesus macaque model. Am J Trop Med Hyg 83:1249-1258

Chu H, Das SC, Fuchs JF, Suresh M, Weaver SC, Stinchcomb DT, Partidos CD, Osorio JE (2013) Deciphering the protective role of adaptive immunity to CHIKV/IRES a novel candidate vaccine against Chikungunya in the A129 mouse model. Vaccine 31:3353-3360

Chua C-L, Sam I-C, Merits A, Chan Y-F (2016) Antigenic variation of East/Central/South African and Asian Chikungunya virus genotypes in neutralization by immune Sera. PLoS Negl Trop Dis 10:e0004960 
Coffman RL, Sher A, Seder RA (2010) Vaccine adjuvants: putting innate immunity to work. Immunity 33:492-503

Coller B-AG, Blue J, Das R, Dubey S, Finelli L, Gupta S, Helmond F, Grant-Klein RJ, Liu K, Simon J, Troth S, VanRheenen S, Waterbury J, Wivel A, Wolf J, Heppner DG, Kemp T, Nichols R, Monath TP (2017) Clinical development of a recombinant Ebola vaccine in the midst of an unprecedented epidemic. Vaccine 35:4465-4469

Combredet C, Labrousse V, Mollet L, Lorin C, Delebecque F, Hurtrel B, McClure H, Feinberg MB, Brahic M, Tangy F (2003) A molecularly cloned Schwarz strain of measles virus vaccine induces strong immune responses in macaques and transgenic mice. J Virol $77: 11546-11554$

Couderc T, Chretien F, Schilte C, Disson O, Brigitte M (2008a) A mouse model for Chikungunya: young age and inefficient type-I interferon signaling are risk factors for severe disease. PLoS ...

Couderc T, Chrétien F, Schilte C, Disson O, Brigitte M, Guivel-Benhassine F, Touret Y, Barau G, Cayet N, Schuffenecker I, Desprès P, Arenzana-Seisdedos F, Michault A, Albert ML, Lecuit M (2008b) A mouse model for Chikungunya: young age and inefficient type-I interferon signaling are risk factors for severe disease. PLoS Pathog 4:e29

Couderc T, Khandoudi N, Grandadam M, Visse C, Gangneux N, Bagot S, Prost J-F, Lecuit M (2009) Prophylaxis and therapy for Chikungunya virus infection. J Infect Dis 200:516-523

de Swart RL, DeSwart RL (2009) Measles studies in the macaque model. Curr Top Microbiol Immunol 330:55-72

de Brito CAA, Sohsten AKAV, Leitão CC de S, Brito R de CCM de, Valadares LDDA, Fonte CAMD, Mesquita ZB de, Cunha RV, Luz K, Leão HMC, Brito CM de, Frutuoso LCV (2016) Pharmacologic management of pain in patients with Chikungunya: a guideline. Rev Soc Bras Med Trop 49:668-679

Diallo D, Sall AA, Buenemann M, Chen R, Faye O, Diagne CT, Faye O, Ba Y, Dia I, Watts D, Weaver SC, Hanley KA, Diallo M (2012) Landscape ecology of sylvatic chikungunya virus and mosquito vectors in southeastern Senegal. PLoS Negl Trop Dis 6:e1649

Draper SJ, Cottingham MG, Gilbert SC (2013) Utilizing poxviral vectored vaccines for antibody induction-progress and prospects. Vaccine 31:4223-4230

Eckels KH, Harrison VR, Hetrick FM (1970) Chikungunya virus vaccine prepared by Tween-ether extraction. Appl Microbiol 19:321-325

Edelman R, Tacket CO, Wasserman SS, Bodison SA, Perry JG, Mangiafico JA (2000) Phase II safety and immunogenicity study of live Chikungunya virus vaccine TSI-GSD-218. Am J Trop Med Hyg 62:681-685

Enserink M (2007) Infectious diseases. Chikungunya: no longer a third world disease. Science. American Association for the Advancement of Science

Erasmus JH, Needham J, Raychaudhuri S, Diamond MS, Beasley DWC, Morkowski S, Salje H, Fernandez-Salas I, Kim DY, Frolov I, Nasar F, Weaver SC (2015) Utilization of an eilat virus-based chimera for serological detection of Chikungunya infection. PLoS Negl Trop Dis 9:e0004119

Erasmus JH, Auguste AJ, Kaelber JT, Luo H, Rossi SL, Fenton K, Leal G, Kim DY, Chiu W, Wang T, Frolov I, Nasar F, Weaver SC (2016) A Chikungunya fever vaccine utilizing an insect-specific virus platform. Nat Med 23:192-199

Ewer K, Sebastian S, Spencer AJ, Gilbert S, Hill AVS, Lambe T (2017) Chimpanzee adenoviral vectors as vaccines for outbreak pathogens. Hum Vaccin Immunother 13:3020-3032

Fox JM, Long F, Edeling MA, Lin H, van Duijl-Richter MKS, Fong RH, Kahle KM, Smit JM, Jin J, Simmons G, Doranz BJ, Crowe JE Jr, Fremont DH, Rossmann MG, Diamond MS (2015) Broadly neutralizing alphavirus antibodies bind an epitope on E2 and inhibit entry and egress. Cell 1-14

Galatas B, Ly S, Duong V, Baisley K, Nguon K, Chan S, Huy R, Ly S, Sorn S, Som L, Buchy P, Tarantola A (2016) Long-lasting immune protection and other epidemiological findings after Chikungunya emergence in a Cambodian rural community, April 2012. PLoS Negl Trop Dis 10:e0004281 
García-Arriaza J, Cepeda V, Hallengärd D, Sorzano CÓS, Kümmerer BM, Liljeström P, Esteban M (2014) A novel poxvirus-based vaccine, MVA-CHIKV, is highly immunogenic and protects mice against Chikungunya infection. J Virol 88:3527-3547

Gardner J, Anraku I, Le TT, Larcher T, Major L, Roques P, Schroder WA, Higgs S, Suhrbier A (2010) Chikungunya virus arthritis in adult wild-type mice. J Virol 84:8021-8032

Gardner CL, Burke CW, Higgs ST, Klimstra WB, Ryman KD (2012) Interferon-alpha/beta deficiency greatly exacerbates arthritogenic disease in mice infected with wild-type chikungunya virus but not with the cell culture-adapted live-attenuated 181/25 vaccine candidate. Virology 425:103-112

Gardner CL, Hritz J, Sun C, Vanlandingham DL, Song TY, Ghedin E, Higgs S, Klimstra WB, Ryman KD (2014) Deliberate attenuation of chikungunya virus by adaptation to heparan sulfate-dependent infectivity: a model for rational arboviral vaccine design. PLoS Negl Trop Dis 8:e2719

Genzel Y (2015) Designing cell lines for viral vaccine production: Where do we stand? Biotechnol J 10:728-740

Godaert L, Najioullah F, Bartholet S, Colas S, Yactayo S, Cabié A, Fanon J-L, Césaire R, Dramé M (2017) Atypical clinical presentations of acute phase Chikungunya virus infection in older adults. J Am Geriatr Soc 65:2510-2515

Goo L, Dowd KA, Lin T-Y, Mascola JR, Graham BS, Ledgerwood JE, Pierson TC (2016) A virus-like particle vaccine elicits broad neutralizing antibody responses in humans to All Chikungunya virus genotypes. J Infect Dis 214:1487-1491

Gorchakov R, Wang E, Leal G, Forrester NL, Plante K, Rossi SL, Partidos CD, Adams AP, Seymour RL, Weger J, Borland EM, Sherman MB, Powers AM, Osorio JE, Weaver SC (2012) Attenuation of Chikungunya virus vaccine strain 181/clone 25 is determined by two amino acid substitutions in the E2 envelope glycoprotein. J Virol 86:6084-6096

Haese NN, Broeckel RM, Hawman DW, Heise MT, Morrison TE, Streblow DN (2016) Animal models of Chikungunya virus infection and disease. J Infect Dis 214:S482-S487

Haglund K, Leiner I, Kerksiek K, Buonocore L, Pamer E, Rose JK (2002) High-level primary CD8 (+) T-cell response to human immunodeficiency virus type 1 gag and env generated by vaccination with recombinant vesicular stomatitis viruses. J Virol 76:2730-2738

Hallengard D, Lum FM, Kummerer BM, Lulla A, Lulla V, Garcia-Arriaza J, Fazakerley JK, Roques P, Le Grand R, Merits A, Ng LFP, Esteban M, Liljestrom P (2014) Prime-boost immunization strategies against Chikungunya virus. J Virol

Hallengärd D, Kakoulidou M, Lulla A, Kümmerer BM, Johansson DX, Mutso M, Lulla V, Fazakerley JK, Roques P, Le Grand R, Merits A, Liljeström P (2014) Novel attenuated Chikungunya vaccine candidates elicit protective immunity in C57BL/6 mice. J Virol $88: 2858-2866$

Harrison VR, Eckels KH, Bartelloni PJ, Hampton C (1971) Production and evaluation of a formalin-killed Chikungunya vaccine. J Immunol 107:643-647

Hawman DW, Stoermer KA, Montgomery SA, Pal P, Oko L, Diamond MS, Morrison TE (2013) Chronic joint disease caused by persistent Chikungunya virus infection is controlled by the adaptive immune response. J Virol 87:13878-13888

Hoarau JJ, Gay F, Pellé O, Samri A, Jaffar-Bandjee MC, Gasque P, Autran B (2013) Identical strength of the $\mathrm{T}$ cell responses against E2, nsP1 and capsid CHIKV proteins in recovered and chronic patients after the epidemics of 2005-2006 in La Reunion Island. PLoS ONE 8:e84695

Hu M-M, Shu H-B (2018) Cytoplasmic mechanisms of recognition and defense of microbial nucleic acids. Annu Rev Cell Dev Biol

Iwasaki A, Medzhitov R (2015) Control of adaptive immunity by the innate immune system. Nat Immunol 16:343-353

Kam Y-W, Lee WWL, Simarmata D, Harjanto S, Teng T-S, Tolou H, Chow A, Lin RTP, Leo Y-S, REnia L, Ng LFP (2012) Longitudinal analysis of the human antibody response to Chikungunya virus infection: implications for serodiagnosis and vaccine development. J Virol 86:13005-13015 
Kam Y-W, Simarmata D, Chow A, Her Z, Teng T-S, Ong EKS, REnia L, Leo Y-S, Ng LFP (2012a) Early appearance of neutralizing immunoglobulin G3 antibodies is associated with Chikungunya virus clearance and long-term clinical protection. J Infect Dis 205:1147-1154

Kam Y-W, Lum F-M, Teo T-H, Lee WWL, Simarmata D, Harjanto S, Chua C-L, Chan Y-F, Wee J-K, Chow A, Lin RTP, Leo Y-S, Le Grand R, Sam I-C, Tong J-C, Roques P, Wiesmüller K-H, REnia L, Rötzschke O, Ng LFP (2012b) Early neutralizing IgG response to Chikungunya virus in infected patients targets a dominant linear epitope on the E2 glycoprotein. EMBO Mol Med 4:330-343

Khan M, Dhanwani R, Rao PVL, Parida M (2012) Subunit vaccine formulations based on recombinant envelope proteins of Chikungunya virus elicit balanced Th1/Th2 response and virus-neutralizing antibodies in mice. Virus Research 167:236-246

Kim DY, Atasheva S, Foy NJ, Wang E, Frolova EI, Weaver S, Frolov I (2011) Design of chimeric alphaviruses with a programmed, attenuated, cell type-restricted phenotype. J Virol 85:43634376

Kose N, Fox JM, Sapparapu G, Bombardi R, Tennekoon RN, de Silva AD, Elbashir SM, Theisen MA, Humphris-Narayanan E, Ciaramella G, Himansu S, Diamond MS, Crowe JE (2019) A lipid-encapsulated mRNA encoding a potently neutralizing human monoclonal antibody protects against Chikungunya infection. Sci Immunol 4:eaaw6647

Kumar M, Sudeep AB, Arankalle VA (2012) Evaluation of recombinant E2 protein-based and whole-virus inactivated candidate vaccines against Chikungunya virus. Vaccine 30:6142-6149

Lanciotti RS, Valadere AM (2014) Transcontinental movement of Asian genotype Chikungunya virus. Emerging Infect Dis 20:1400-1402

Lang PO, Loulergue P, Aspinall R (2017) Chikungunya Virus Infection: Why Should U.S. Geriatricians Be Aware of It? J Am Geriatr Soc 65:2529-2534

Langsjoen RM, Haller SL, Roy CJ, Vinet-Oliphant H, Bergren NA, Erasmus JH, Livengood JA, Powell TD, Weaver SC, Rossi SL (2018) Chikungunya virus strains show lineage-specific variations in virulence and cross-protective ability in murine and nonhuman primate models. mBio 9:e02449-17-13

Leparc-Goffart I, Nougairede A, Cassadou S, Prat C, de Lamballerie X (2014) Chikungunya in the Americas. Lancet 383:514

Levitt NH, Ramsburg HH, Hasty SE, Repik PM, Cole FE, Lupton HW (1986) Development of an attenuated strain of Chikungunya virus for use in vaccine production. Vaccine 4:157-162

Levy O, Goriely S, Kollmann TR (2013) Immune response to vaccine adjuvants during the first year of life. Vaccine 31:2500-2505

Liu MA (2010) Immunologic basis of vaccine vectors. Immunity 33:504-515

Lloyd J, Cheyne J (2017) The origins of the vaccine cold chain and a glimpse of the future. Vaccine 35:2115-2120

Lum F-M, Teo T-H, Lee WWL, Kam Y-W, REnia L, Ng LFP (2013) An essential role of antibodies in the control of Chikungunya virus infection. J Immunol 190:6295-6302

Majhen D, Calderon H, Chandra N, Fajardo CA, Rajan A, Alemany R, Custers J (2014) Adenovirus-based vaccines for fighting infectious diseases and cancer: progress in the field. Human Gene Ther 25:301-317

Mallilankaraman K, Shedlock DJ, Bao H, Kawalekar OU, Fagone P, Ramanathan AA, Ferraro B, Stabenow J, Vijayachari P, Sundaram SG, Muruganandam N, Sarangan G, Srikanth P, Khan AS, Lewis MG, Kim JJ, Sardesai NY, Muthumani K, Weiner DB (2011) A DNA vaccine against Chikungunya virus is protective in mice and induces neutralizing antibodies in mice and nonhuman primates. PLoS Negl Trop Dis 5:e928

Messaoudi I, Vomaske J, Totonchy T, Kreklywich CN, Haberthur K, Springgay L, Brien JD, Diamond MS, Defilippis VR, Streblow DN (2013) Chikungunya virus infection results in higher and persistent viral replication in aged rhesus macaques due to defects in anti-viral immunity. PLoS Negl Trop Dis 7:e2343 
Metz SW, Gardner J, Geertsema C, Le TT, Goh L, Vlak JM, Suhrbier A, Pijlman GP (2013a) Effective Chikungunya virus-like particle vaccine produced in insect cells. PLoS Negl Trop Dis 7:e2124

Metz SW, Martina BE, van den Doel P, Geertsema C, Osterhaus AD, Vlak JM, Pijlman GP (2013b) Chikungunya virus-like particles are more immunogenic in a lethal AG129 mouse model compared to glycoprotein E1 or E2 subunits. Vaccine 31:6092-6096

Mohsen MO, Zha L, Cabral-Miranda G, Bachmann MF (2017) Major findings and recent advances in virus-like particle (VLP)-based vaccines. Semin Immunol 34:123-132

Morrison TE, Oko L, Montgomery SA, Whitmore AC, Lotstein AR, Gunn BM, Elmore SA, Heise MT (2011) A mouse model of Chikungunya virus-induced musculoskeletal inflammatory disease. AJPA 178:32-40

Moss B, Carroll MW, Wyatt LS, Bennink JR, Hirsch VM, Goldstein S, Elkins WR, Fuerst TR, Lifson JD, Piatak M, Restifo NP, Overwijk W, Chamberlain R, Rosenberg SA, Sutter G (1996) Host range restricted, non-replicating vaccinia virus vectors as vaccine candidates. Adv Exp Med Biol 397:7-13

Mühlebach MD (2017) Vaccine platform recombinant measles virus. Virus Genes 53:733-740

Muthumani K, Lankaraman KM, Laddy DJ, Sundaram SG, Chung CW, Sako E, Wu L, Khan A, Sardesai N, Kim JJ, Vijayachari P, Weiner DB (2008) Immunogenicity of novel consensus-based DNA vaccines against Chikungunya virus. Vaccine 26:5128-5134

Muthumani K, Block P, Flingai S, Muruganantham N, Chaaithanya IK, Tingey C, Wise M, Reuschel EL, Chung C, Muthumani A, Sarangan G, Srikanth P, Khan AS, Vijayachari P, Sardesai NY, Kim JJ, Ugen KE, Weiner DB (2016) Rapid and long-term immunity elicited by DNA-encoded antibody prophylaxis and DNA vaccination against Chikungunya virus. J Infect Dis 214:369-378

Nakao E, Hotta S (1973) Immunogenicity of purified, inactivated Chikungunya virus in monkeys. Bull World Health Organ 48:559-562

Nasar F, Gorchakov RV, Tesh RB, Weaver SC (2015) Eilat virus host range restriction is present at multiple levels of the virus life cycle. J Virol (5 ed.) 89:1404-1418

Pal P, Dowd KA, Brien JD, Edeling MA, Gorlatov S, Johnson S, Lee I, Akahata W, Nabel GJ, Richter MKS, Smit JM, Fremont DH, Pierson TC, Heise MT, Diamond MS (2013) Development of a highly protective combination monoclonal antibody therapy against Chikungunya virus. PLoS Pathog 9:e1003312

Partidos CD, Paykel J, Weger J, Borland EM, Powers AM, Seymour R, Weaver SC, Stinchcomb DT, Osorio JE (2012) Cross-protective immunity against o'nyong-nyong virus afforded by a novel recombinant Chikungunya vaccine. Vaccine 30:4638-4643

Piper A, Ribeiro M, Smith KM, Briggs CM, Huitt E, Nanda K, Spears CJ, Quiles M, Cullen J, Thomas ME, Brown DT, Hernandez R (2013) Chikungunya virus host range E2 transmembrane deletion mutants induce protective immunity against challenge in C57BL/6 J Mice. J Virol 87:6748-6757

Plante K, Wang E, Partidos CD, Weger J, Gorchakov R, Tsetsarkin K, Borland EM, Powers AM, Seymour R, Stinchcomb DT, Osorio JE, Frolov I, Weaver SC (2011) Novel Chikungunya vaccine candidate with an IRES-based attenuation and host range alteration mechanism. PLoS Pathog 7:e1002142

Plante KS, Rossi SL, Bergren NA, Seymour RL, Weaver SC (2015) Extended preclinical safety, efficacy and stability testing of a live-attenuated Chikungunya Vaccine candidate. PLoS Negl Trop Dis 9:e0004007-19

Poo YS, Rudd PA, Gardner J, Wilson JAC, Larcher T, Colle M-A, Le TT, Nakaya HI, Warrilow D, Allcock R, Bielefeldt-Ohmann H, Schroder WA, Khromykh AA, Lopez JA, Suhrbier A (2014) Multiple immune factors are involved in controlling acute and chronic Chikungunya virus infection. PLoS Negl Trop Dis 8:e3354-15

Ramsauer K, Tangy F (2016) Chikungunya virus vaccines: viral vector-based approaches. J Infect Dis 214:S500-S505

Ramsauer K, Schwameis M, Firbas C, Müllner M, Putnak RJ, Thomas SJ, Desprès P, Tauber E, Jilma B, Tangy F (2015) Immunogenicity, safety, and tolerability of a recombinant 
measles-virus-based Chikungunya vaccine: a randomised, double-blind, placebo-controlled, active-comparator, first-in-man trial. Lancet Infect Dis 15:519-527

Reed SG, Orr MT, Fox CB (2013) Key roles of adjuvants in modern vaccines. Nat Med 19:15971608

Reisinger EC, Tschismarov R, Beubler E, Wiedermann U, Firbas C, Loebermann M, Pfeiffer A, Muellner M, Tauber E, Ramsauer K (2019) Immunogenicity, safety, and tolerability of the measles-vectored chikungunya virus vaccine MV-CHIK: a double-blind, randomised, placebo-controlled and active-controlled phase 2 trial. Lancet 392:2718-2727

Roberts A, Buonocore L, Price R, Forman J, Rose JK (1999) Attenuated vesicular stomatitis viruses as vaccine vectors. J Virol 73:3723-3732

Roques P, Ljungberg K, Kümmerer BM, Gosse L, Dereuddre-Bosquet N, Tchitchek N, Hallengärd D, García-Arriaza J, Meinke A, Esteban M, Merits A, Le Grand R, Liljeström P (2017) Attenuated and vectored vaccines protect nonhuman primates against Chikungunya virus. JCI Insight 2:e83527

Rossi SL, Comer JE, Wang E, Azar SR, Lawrence WS, Plante JA, Ramsauer K, Schrauf S, Weaver SC (2019) Immunogenicity and efficacy of a measles virus-vectored Chikungunya vaccine in nonhuman primates. $\mathrm{J}$ Infect Dis

Roy CJ, Adams AP, Wang E, Plante K, Gorchakov R, Seymour RL, Vinet-Oliphant H, Weaver SC (2014) Chikungunya vaccine candidate is highly attenuated and protects nonhuman primates against telemetrically monitored disease following a single dose. J Infect Dis 209:1891-1899

Rudd PA, Wilson J, Gardner J, Larcher T, Babarit C, Le TT, Anraku I, Kumagai Y, Loo YM, Gale M, Akira S, Khromykh AA, Suhrbier A (2012) Interferon response factors 3 and 7 protect against Chikungunya virus hemorrhagic fever and shock. J Virol 86:9888-9898

Sahadeo NSD, Allicock OM, De Salazar PM, Auguste AJ, Widen S, Olowokure B, Gutierrez C, Valadere AM, Polson-Edwards K, Weaver SC, Carrington CVF (2017) Understanding the evolution and spread of Chikungunya virus in the Americas using complete genome sequences. Virus Evol 3:vex010-10

Saxena M, Van TTH, Baird FJ, Coloe PJ, Smooker PM (2013) Pre-existing immunity against vaccine vectors-friend or foe? Microbiology (Reading, England) 159:1-11

Seyler T, Hutin Y, Ramanchandran V, Ramakrishnan R, Manickam P, Murhekar M (2010) Estimating the burden of disease and the economic cost attributable to chikungunya, Andhra Pradesh, India, 2005-2006. Trans R Soc Trop Med Hyg 104:133-138

Shaw C, Panther L, August A, Zaks T, Smolenov I, Bart S, Watson M (2019) Safety and immunogenicity of a mRNA-based Chikungunya vaccine in a phase 1 dose-ranging trial. Int $\mathrm{J}$ Infect Dis 79:17

Sheela PJ, Sumathy K (2013) Serological correlates of immune protection conferred by Chikungunya virus infection. Acta Virol 57:471-473

Simmons G, Brès V, Lu K, Liss NM, Brambilla DJ, Ryff KR, Bruhn R, Velez E, Ocampo D, Linnen JM, Latoni G, Petersen LR, Williamson PC, Busch MP (2016) High incidence of Chikungunya virus and frequency of viremic blood donations during epidemic, Puerto Rico, USA, 2014. Emerg Infect Dis 22:1221-1228

Smith SA, Silva LA, Fox JM, Flyak AI, Kose N, Sapparapu G, Khomandiak S, Khomadiak S, Ashbrook AW, Kahle KM, Fong RH, Swayne S, Doranz BJ, McGee CE, Heise MT, Pal P, Brien JD, Austin SK, Diamond MS, Dermody TS, Crowe JE (2015) Isolation and characterization of broad and ultrapotent human monoclonal antibodies with therapeutic activity against Chikungunya virus. Cell Host Microbe 18:86-95

Strauss JH, Strauss EG (1994) The alphaviruses: gene expression, replication, and evolution. Microbiol Rev 58:491-562

Sun S, Xiang Y, Akahata W, Holdaway H, Pal P, Zhang X, Diamond MS, Nabel GJ, Rossmann MG (2013) Structural analyses at pseudo atomic resolution of Chikungunya virus and antibodies show mechanisms of neutralization. eLife 2:e0435

Tangy F, Naim HY (2005) Live attenuated measles vaccine as a potential multivalent pediatric vaccination vector. Viral Immunol 18:317-326 
Taylor A, Herrero LJ, Rudd PA, Mahalingam S (2015) Mouse models of alphavirus-induced inflammatory disease. J Gen Virol 96:221-238

Teo TH, Lum FM, Claser C, Lulla V, Lulla A, Merits A, Renia L, Ng LFP (2012a) A pathogenic role for $\mathrm{CD}^{+} \mathrm{T}$ cells during Chikungunya virus infection in mice. J Immunol 190:259-269

Teo T-H, Lum F-M, Lee WWL, Ng LFP (2012b) Mouse models for Chikungunya virus: deciphering immune mechanisms responsible for disease and pathology. Immunol Res 53:136147

Teo T-H, Her Z, Tan JJL, Lum F-M, Lee WWL, Chan Y-H, Ong R-Y, Kam Y-W, Leparc-Goffart I, Gallian P, REnia L, de Lamballerie X, Ng LFP (2015) Caribbean and La Réunion Chikungunya virus isolates differ in their capacity to induce pro-inflammatory Th1 and NK cell responses and acute joint pathology. J Virol JVI.00909-15-59

Thompson EA, Loré K (2017) Non-human primates as a model for understanding the mechanism of action of toll-like receptor-based vaccine adjuvants. Curr Opin Immunol 47:1-7

Tiwari M, Parida M, Santhosh SR, Khan M, Dash PK, Rao PVL (2009) Assessment of immunogenic potential of Vero adapted formalin inactivated vaccine derived from novel ECSA genotype of Chikungunya virus. Vaccine 27:2513-2522

Tretyakova I, Hearn J, Wang E, Weaver S, Pushko P (2014) DNA vaccine initiates replication of live attenuated Chikungunya virus in vitro and elicits protective immune response in mice. J Infect Dis 209:1882-1890

Tsetsarkin KA, Weaver SC (2011) Sequential adaptive mutations enhance efficient vector switching by Chikungunya virus and its epidemic emergence. PLoS Pathog 7:e1002412

Tsetsarkin K, Higgs S, McGee CE, de Lamballerie X, Charrel RN, Vanlandingham DL (2006) Infectious clones of Chikungunya virus (La Réunion isolate) for vector competence studies. Vector-Borne and Zoonotic Dis 6:325-337

Tsetsarkin KA, Vanlandingham DL, McGee CE, Higgs S (2007) A single mutation in Chikungunya virus affects vector specificity and epidemic potential. PLoS Pathog 3:e201

Tsetsarkin KA, Chen R, Weaver SC (2016) Interspecies transmission and chikungunya virus emergence. Curr Opin Virol 16:143-150

Ulmer JB, Valley U, Rappuoli R (2006) Vaccine manufacturing: challenges and solutions. Nat Biotechnol 24:1377-1383

van den Doel P, Volz A, Roose JM, Sewbalaksing VD, Pijlman GP, van Middelkoop I, Duiverman V, van de Wetering E, Sutter G, Osterhaus ADME, Martina BEE (2014) Recombinant modified vaccinia virus Ankara expressing glycoprotein E2 of Chikungunya virus protects AG129 mice against lethal challenge. PLoS Negl Trop Dis 8:e3101

van Duijl-Richter MKS, Hoornweg TE, Rodenhuis-Zybert IA, Smit JM (2015) Early events in Chikungunya virus infection-from virus cell binding to membrane fusion. Viruses 7:36473674

Vaney M-C, Duquerroy S, Rey FA (2013) Alphavirus structure: activation for entry at the target cell surface. Curr Opin Virol 3:151-158

Vanlandingham DL, Tsetsarkin K, Hong C, Klingler K, McElroy KL, Lehane MJ, Higgs S (2005) Development and characterization of a double subgenomic Chikungunya virus infectious clone to express heterologous genes in Aedes aegypti mosquitoes. Insect Biochem Mol Biol $35: 1162-1170$

Vasilakos JP, Tomai MA (2013) The use of toll-like receptor 7/8 agonists as vaccine adjuvants. Expert Rev Vaccines 12:809-819

Volk SM, Chen R, Tsetsarkin KA, Adams AP, Garcia TI, Sall AA, Nasar F, Schuh AJ, Holmes EC, Higgs S, Maharaj PD, Brault AC, Weaver SC (2010) Genome-scale phylogenetic analyses of Chikungunya virus reveal independent emergences of recent epidemics and various evolutionary rates. J Virol 84:6497-6504

Volz A, Sutter G (2017) Modified vaccinia virus Ankara: history, value in basic research, and current perspectives for vaccine development. Adv Virus Res 97:187-243

Voss JE, Vaney M-C, Duquerroy S, Vonrhein C, Girard-Blanc C, Crublet E, Thompson A, Bricogne G, Rey FA (2010) Glycoprotein organization of Chikungunya virus particles revealed by X-ray crystallography. Nature 468:709-712 
Wang E, Volkova E, Adams AP, Forrester N, Xiao S-Y, Frolov I, Weaver SC (2008) Chimeric alphavirus vaccine candidates for Chikungunya. Vaccine 26:5030-5039

Wang E, Kim DY, Weaver SC, Frolov I (2011a) Chimeric Chikungunya viruses are nonpathogenic in highly sensitive mouse models but efficiently induce a protective immune response. J Virol 85:9249-9252

Wang D, Suhrbier A, Penn-Nicholson A, Woraratanadharm J, Gardner J, Luo M, Le TT, Anraku I, Sakalian M, Einfeld D, Dong JY (2011b) A complex adenovirus vaccine against chikungunya virus provides complete protection against viraemia and arthritis. Vaccine 29:2803-2809

Weger-Lucarelli J, Chu H, Aliota MT, Partidos CD, Osorio JE (2014) A novel MVA vectored Chikungunya virus vaccine elicits protective immunity in mice. PLoS Negl Trop Dis 8:e2970

Weger-Lucarelli J, Aliota MT, Kamlangdee A, Osorio JE (2015) Identifying the role of E2 domains on alphavirus neutralization and protective immune responses. PLoS Negl Trop Dis 9: e0004163-17

Wei Chiam C, Fun Chan Y, Chai Ong K, Thong Wong K, Sam I-C (2015) Neurovirulence comparison of chikungunya virus isolates of the Asian and East/Central/South African genotypes from Malaysia. J Gen Virol 96:3243-3254

Yoon I-K, Alera MT, Lago CB, Tac-An IA, Villa D, Fernandez S, Thaisomboonsuk B, Klungthong C, Levy JW, Velasco JM, Roque VG, Salje H, Macareo LR, Hermann LL, Nisalak A, Srikiatkhachorn A (2015) High rate of subclinical Chikungunya virus infection and association of neutralizing antibody with protection in a prospective cohort in the Philippines. PLoS Negl Trop Dis 9:e000376

Ziegler SA, Lu L, da Rosa APAT, Xiao S-Y, Tesh RB (2008) An animal model for studying the pathogenesis of Chikungunya virus infection. Am J Trop Med Hyg 79:133-139 